\title{
A RETROSPECTIVE ON THE DEBT CRISIS
}

Michael P. Dooley

Working Paper No. 4963

\section{NATIONAL BUREAU OF ECONOMIC RESEARCH 1050 Massachusetts Avenue Cambridge, MA 02138 \\ December 1994}

I would like to thank Polly Allen, Peter Kenen and Ken Rogoff for their helpful comments. This paper is part of NBER's research program in International Finance and Macroeconomics. Any opinions expressed are those of the author and not those of the National Bureau of Economic Research.

(C) 1994 by Michael P. Dooley. All rights reserved. Short sections of text, not to exceed two paragraphs, may be quoted without explicit permission provided that full credit, including $(\mathcal{C}$ notice, is given to the source. 


\title{
A RETROSPECTIVE ON THE DEBT CRISIS
}

\begin{abstract}
In this paper I argue that the international debt crisis of 1982 can best be understood as a prolonged negotiation between commercial banks and their own governments over who would bear the economic losses generated by loans made to developing countries. This interpretation of the debt crisis is contrasted with the more familiar approach that emphasizes conflict between debtor countries and their creditors.

The main conclusion is that the failure of governments of industrial countries to resolve this conflict with their banks transformed an unremarkable financial crisis into a decade-long economic crisis for debtor countries. The analysis also suggests that recent capital inflows to developing countries are less likely to generate the same economic costs for debtor countries even if changes in the economic environment generate similar losses for investors.
\end{abstract}

Michael P. Dooley

Department of Economics, Social Sciences I

University of California, Santa Cruz

Santa Cruz, CA 95064

and NBER 
I. Introduction

In 1992 private capital inflows to Mexico equaled eight percent of that country's GDP and if the pace of inflows thus far in 1993 and 1994 continues, the inflow relative to GDP will be even larger. This private capital inflow was larger than in any year before Mexico suspended debt service payments in 1982 , the action that is usually considered the beginning of the debt crisis that dominated economic developments in many developing countries for a decade. The resurgence of private capital inflows to developing countries has been widely distributed but has been particularly evident in developing countries that did not experience debt servicing difficulties and countries that have participated in Brady Plan rescheduling agreements (Calvo, Leiderman and Reinhart, 1993).

This remarkable turnaround makes a retrospective of what has been called a "lost decade" of economic stagnation for debtor countries particularly important. ${ }^{2}$ only a few years ago experts agreed that developing countries would not return to private international credit markets for a generation. Do we

${ }^{2}$ See Dooley and Corden (1989), Cohen (1991, 1992), Cooper (1992) and Arora (1993) for comprehensive reviews of the debt crisis. 
understand enough about the 1982 crisis to predict that renewed accumulation of external debt will not lead to a repeat of 1982 and the considerable costs that followed for debtor countries? Unless the memories of investors and debtor country governments are very short they must believe that there is a difference in the expected outcome of this new round of international lending.

It is very likely that economic developments external to the debtor countries, particularity recent declines in interest rates in industrial countries, explain an important share of recent capital inflows (Bulow, Rogoff and Bevilaqua, 1992; Dooley and stone, 1993). It follows that highly indebted developing countries remain vulnerable to external shocks, particularly a combination of recession and high real interest rates in industrial countries. However, the analysis of the 1982 crisis developed below suggests that the recent buildup in external debt is unlikely to generate the economic costs for debtor countries that followed the 1982 crisis, even if bad luck or bad policies lead to another round of debt servicing difficulties. In contrast, debtor countries that have not restructured and reduced their debt to commercial banks are vulnerable to a return to economic stagnation.

The basic idea is that the enormous costs borne by debtor countries after 1982 were the result of prolonged selfinterested bargaining between the commercial banks and their own governments. The new buildup of debt will not generate 
similar bargaining because recent lending has not involved the commercial banks of industrial countries.

The origins of the bargaining game between international banks and industrial country governments are found in relationships among creditors established long before the summer of 1982 when the government of Mexico announced that it was unable to meet its debt service obligations. For this reason we begin a brief historical review of what has come to be known as the debt crisis of 1982 with the buildup of the external debt of developing countries in the 1970s.

II. Accumulation of External Debt 1970-82

a. Historical review

The striking aspect of the buildup in debt before 1982 is the dominant role of international commercial banks in providing medium and long term credits to residents of developing countries. Following widespread defaults on international bonds issued by developing countries in the 1930 s lending to developing countries before 1974 was generally restricted to government-to-government loans or loans from international organizations such as the World Bank and the International Monetary Fund. One of the keys to the interpretation of the debt crisis offered in this paper is that the emergence of banks as the financial intermediaries in the 1970 s can best be understood as a process in which banks replaced governments of industrial countries as lenders to developing countries but did 
so with the approval, encouragement and implicit support of governments of industrial countries.

The economics behind the buildup in debt is

straightforward. The dramatic rise in the price of oil in 1974 and again in 1979 generated huge current account surpluses for oil exporting countries. As shown in Table 1 the counterpart of the oil exporters current account surpluses' was deficits for both industrial and developing countries. Oil exporters' current account surpluses reflected their desire to smooth consumption. This implied that a large share of revenues had to be "recycled" to oil importing countries in the form of capital flows from oil exporters to oil importers.

The economics behind the pattern of financial intermediation between surplus and deficit countries is much less obvious. While private capital markets were the obvious vehicle for capital inflows to industrial countries, the traditional pattern would have been for governments and international organizations to act as intermediaries for lending to developing countries. Governments, particularity the US government, however, were not anxious to take on this responsibility directly through an expansion of government-togovernment loans or indirectly through international organizations such as the World Bank or the International Monetary Fund.

Oil exporters were also an unlikely source of direct credit for developing countries. In fact, oil exporting countries realized that they were not the most popular investors in the 
Table 1

Current Account Balances

(billions of U.S. dollars)

\begin{tabular}{|c|c|c|c|}
\hline & A11 Industrial Countries & Fuel Exporters & Non-Fuel Exporters \\
\hline 1970 & 6 & $(2)$ & $-(9)$ \\
\hline 1971 & 9 & 1 & $-(11)$ \\
\hline 1972 & 6 & 2 & $-(5)$ \\
\hline 1973 & 11 & 6 & $-(4)$ \\
\hline 1974 & $-(27)$ & 65 & $-(22)$ \\
\hline 1975 & 7 & 33 & $-(31)$ \\
\hline 1976 & $-(15)$ & 31 & $-(18)$ \\
\hline 1977 & $-(20)$ & 20 & $-(13)$ \\
\hline 1978 & 11 & $-(5)$ & $-(21)$ \\
\hline 1979 & $-(27)$ & 53 & $-(32)$ \\
\hline 1980 & $-(64)$ & 94 & $-(52)$ \\
\hline 1981 & $-(23)$ & 32 & $-(68)$ \\
\hline 1982 & $-(27)$ & $-(20)$ & $-(59)$ \\
\hline IMF World Economic Outlook & & \\
\hline \multicolumn{5}{|l|}{} \\
\hline
\end{tabular}


world at the time wanted financial assets that were as Iiquid and immune from political reprisals as possible. Direct loans to residents of developing countries did not fit this description.

In contrast, commercial banks saw recycling oil money as a profitable new business. Bank deposits were an ideal instrument from the point of view of petroleum exporters. Banks operated in many offshore banking centers and deposits were typically passed on to several banks in different countries before being loaned to a nonbank. Thus there was no correspondence between the location of a deposit and the location of the ultimate loan to a nonbank. Moreover, it was generally recognized that banks were special institutions that had proven to be "too big to fail." Governments had consistently stepped in to save a large bank in order to prevent a general financial panic.

on the other side, borrowers in both industrial and developing countries preferred bank credits to more traditional private and official financial intermediaries because banks were willing to charge only a small margin over their cost of funds when setting lending rates. The wisdom of banks in entering into this business and lending at very narrow spreads to compensate for credit risk has been widely questioned in recent years. Our interpretation of this phase of the crisis is that banks were rational in the sense that they realized a bad outcome was possible but also realized that losses 
generated by bad outcomes could be shifted to their own governments.

In summary, the buildup in external debt in the 1970s is generally attributed to a series of external events that seemed to provide economic reasons for lending to developing countries. Relative price increases for oil and other commodities provided a demand for credit and the OPEC surplus provided a supply of internationally mobile savings. Low ex post real interest rates on loans denominated in major currencies may have contributed to the willingness of residents of developing countries to incur debt, although low interest rates should have encouraged other borrowers equally.

\section{b. Policy during the buildup of debt}

The hypothesis that banks relied on their own government's implicit guarantee of their loans to developing countries has the advantage that it explains implausibly naive statements of bankers about the "inability of countries to fail." The one thing that could stop the banks from taking on this profitable but risky loan portfolio was the attitude of regulators toward country risk. The banks knew that their exposure to individual countries was much larger than would normally be permitted under domestic concentration ratios. Thus, the banks had every incentive to take the risky positions but at the same time to reassure the regulators that there was no risk involved.

An alternative interpretation is that banks really were naive but after the crisis occurred banks turned to their 
governments for a bailout and used the earlier official support for recycling oil money as a convenient ex post rationalization. The banks were quick to point out after 1982 that "the public and government applauded them for successfully 'recycling' the soaring revenue of oil-producing countries in the 1970s" (Rout, 1983).

The conjecture that creditor governments were expected ex ante to guarantee bank claims on developing countries is important to the interpretation of the buildup in debt presented here but is less important to our interpretation of the bargaining between banks and their governments that followed. In either case the banks saw a good chance of collecting on their developing country loans from their own governments. The policy decision that led to protracted negotiations between the banks and creditor governments was the refusal of conservative governments in the United States and other industrial countries to provide the expected backup. The longer this game went on, the higher was the loss to the debtor countries.

There is ample evidence that the implicit back up provided by creditor governments was recognized before the debt crisis became apparent in 1982. As early as 1974 Arthur Burns, then Chairman of the Federal Reserve Board, warned that banks were taking excessive risks in international lending (Burns, 1978). Governor Henry Wallich $(1981,1987)$ of the Board of Governors repeatedly pointed out before 1982 that banks' exposure to 
sovereign risk threatened their capital and that additional lending should be constrained by the regulatory authorities. Economists also pointed out the potential problem of excessive concentration of country risk on banks' balance sheets. Kereken (1978) warned that "at the end of 1976 citibank had LDC loans amounting to about 6 percent of its total assets. And we know it had capital, as conventionally measured, amounting to 5 percent of its assets. That suggests, at least to me, that there may be some slight danger, particularity if citibank is not all that untypical. The Federal Reserve, which along with other central banks can make good loans out of bad, may in certain circumstances, be tempted to do just that." Marina Whitman (1978) argued that the official sector should play a larger role in intermediating oil surpluses through the IMF and pointed out that "Should the pessimists turn out to be right, and wide spread defaults loom, the American banks would look for bailout not to an IMF facility totaling less than $\$ 10$ billion, but to the incomparably greater resources of our own Federal Reserve system."

In contrast the US Treasury consistently argued that the banks were the preferred financial intermediaries for loans to developing countries. As Margaret De Vries (1985) documents in her history of the IMF, Treasury Secretary william Simon was the main opponent to an expanded role for official lending through the IMF. Moreover as Weintraub (1983) points out, the 
US Treasury had encouraged US banks to pursue international lending long before the first oil shock.

Finally, the fact that regulatory agencies allowed banks to "bet the bank" on loans to individual countries suggests that there was a consensus that the public benefits of smoothly and efficiently recycling oil money exceeded the potential costs of bailing out the banks. Wellons (1987) documents the cautious approach taken by us regulators in defining lending limits to developing countries and argues that us bank regulators reacted to strong political pressure not to interfere with recycling to developing countries by enforcing lending limits to individual countries.

In summary, the governments of industrial countries had conflicting policy objectives. Oil money had to be recycled but the governments did not want to do it themselves. Moreover, the majority of industrial countries were not enthusiastic about international organizations expanding their role as financial intermediaries. A widely held view was that market forces would lead to the most efficient allocation of financial resources across countries.

Was it rational for governments of industrial countries to permit their banks to intermediate loans to developing countries? It could be argued that the industrial countries had little choice. The financial intermediation was thought to be important to maintain aggregate demand in the oil consuming world. If this premise is accepted, some government or private institution had to accept the country risk associated with 
international lending. The governments of industrial countries seem to have believed that the official lending arrangements were not very good at identifying the most efficient allocation of funds across countries. In fact, the banks pointed out that they were experts at the analysis of country risk and that the discipline of the market place was preferred to bureaucratic decisions in the IMF or other multilateral institutions (Irving Friedman, 1977). But in the following pages it is argued that, once committed, it was a major policy error for creditor governments to refuse to provide the expected backstop. This policy choice transformed an unremarkable financial crisis into a decade long economic crisis for debtor countries.

c. Analytical literature during the buildup.

The buildup of external debt of developing countries generated a substantial academic literature both before the crisis of 1982 and after. The majority of papers before the crisis dealt with the ability of the debtor countries to repay their loans. Until very late in the day the consensus was that servicing the loans was very unlikely to become a problem (Solomon, 1977).

In retrospect, the most important element that seems to have been entirely missing from the evaluation of debtor countries during the years when debt was growing rapidly, was the fact that the private sector of the debtor country was typically accumulating gross claims on the rest of the world at 
an impressive rate. ${ }^{3}$ There are several reasons why what later came to be known as capital flight was entirely missed at the time. Private capital outflows from the debtor countries were largely unrecorded and did not show up in balance of payment statistics of debtor or creditor countries. Perhaps more surprising, in many cases medium and long term borrowing was also not reported in debtor country balance of payments statistics even when it carried official guarantees.

The lack of attention to gross capital flows may be explained by the fact that as long as all goes well there is no particular reason to be concerned about the scale of financial intermediation. It is only after an accident that we have to sort out the consequences for different groups of debtors and creditors. The cost of the debt crisis to debtor countries arose largely because of the perverse incentives generated by the participants jockeying for position in this workout process. Cooper (1992) makes the interesting point that the fact that a substantial part of the stock of external debt was "matched " by capital flight is one reason why creditor governments were unwilling to support proposals that would have provided the bailout the banks had bargained for.

3 See Dooley (1986) for estimates of the stock of flight capital for debtor countries and comparisons between balance of payments data and debtor reporting system estimates for external debt. In 1983 the author and others prepared a paper for the Board of Governors of the Federal Reserve system that provided comprehensive statistical estimates of capital flight. See Dooley et al (1986). 
There were interesting attempts to explain why banks had "overlent" to developing countries. Kletzer (1984) argued that the fact that banks were poorly informed about the loans other banks had or would make to developing countries could account for what appeared ex post to be excessive lending. Gutentag and Herring (1986) argued that banks and most of the rest of us seem to suffer from "disaster myopia" in the sense that really bad outcomes are systematically ignored by decision makers. Devlin (1989) argued that banks are complex organizations that tend to do what other banks are doing to maintain market share. He also mentions the possibility that banks have to keep growing so that they remain too large to fail.

our explanation is that banks acted rationally. If all had gone well they expected to enjoy substantial profits. If things went badly they planned to shift the loans to their government on terms that were not well-defined but that were unlikely to make the decision to make the loans a bad one. In the event of trouble, creditor governments were expected to "nationalize" the banks' claims on developing countries and then collect as best they could. This argument is appealing because it avoids the need to invent naive or poorly informed bankers (a specimen I have seldom encountered in the course of negotiations over restructuring packages). More important it provides a better basis for understanding the negotiations that followed the 1982 crisis. 
III. A Banking Crisis

a. Historical review

Financial intermediation through commercial banks that had developed to accommodate international transactions among residents of industrial countries was easily modified to channel funds to, and from, developing countries. Moreover, syndicated credits commonly used in Euromarkets were uncritically adopted for lending to developing countries. Unfortunately, just as generals prepare to fight the previous war, financial markets design contracts to accommodate the previous shock. The floating rate loan contracts utilized for the bulk of commercial bank lending to developing countries were ready for an increase in the rate of inflation (the dominant shock in the 1970s) but the shock in 1982 was recession and a fall in the rate of inflation in industrial countries accompanied by a spectacular and durable rise in real interest rates, a rise in the real value of the dollar and a fall in the relative prices of oil and other commodities. In my view this was, ex ante, a very low probability shock to the system. No one predicted in the late 1970 s that a conservative Republican president would generate fiscal deficits that far exceeded any outside of major wars and that the Federal Reserve would launch a major disinflation initiative at the same time.

The resulting rise in the real interest rate on dollardenominated loans to developing countries fell entirely on the debtors. The floating interest rate credits that generated this 
result were widely used in Euromarket lending and were a natural reaction to the inflationary shock in industrial countries in the 1970s. Commercial banks had learned the hard way that fixed interest assets placed them at risk in the event of unexpected increases in inflation rates. The popularity of floating rate loans was based on the fact that both the banks and debtors would be protected from surprises in the inflation rate by floating interest rate contracts. For this reason the dominant form of debt contract for all international lending was medium term in maturity but the interest rate was adjusted twice yearly and was tied to the six month LIBOR for the currency of denomination.

The banks hedged currency risk and interest rate risk by matching deposits to loans. Thus, the surprise in real interest rates was shifted entirely and almost immediately to the debtor countries and for this reason contributed to credit risk. The spread over LIBOR on loans determined profit margins and presumably reflected expected losses due to credit risk. As is natural for banks, their attitude toward credit risk was influenced less by the quality of the borrower than the quality of her collateral. In this case the collateral was first a debtor government guarantee of loans to residents of developing countries and ultimately the political commitment of a creditor country government to the debtor government.

In this environment banks did what came naturally. The credits were at risk given the new economic conditions so they called the collateral, pointing out that they had been asked to 
recycle the oil money and that the solvency of the banking system was very important to the governments of the industrial countries.

b. Policy response and damage control

The initial reaction to the banks refusal to roll over credits was as expected. First, private developing country debt was rapidly transformed into developing country government debt even in countries like chile where there was no formal guarantee and the government had said that it would not step in to bail out private debtors. Second, there were immediate calls on the treasuries of creditor countries to provide the debtor governments with the means to meet their obligations to the banks. ${ }^{4}$

Third, bank regulators in all the industrial countries reassured the markets that they would not close banks whose capital was threatened by losses on developing country loans.

But the surprise was that the creditor governments refused to provide the banks with an opportunity to sell their doubtful credits to their governments on any terms, favorable or not. Proposals for a comprehensive debt facility were met with considerable hostility in several important creditor countries. The strategy instead was to "coordinate" continued bank

4 This usually took the form of "bridge loans" until more formal official loans could be arranged. See Sachs (1989) for a description of the immediate official response to the crisis. 
lending until International Monetary Fund programs put the debtor countries back on their feet. Thus, the initial official credit was typically a short-term, bridge loan that was expected to be liquidated after a few months by an IMF credit. Some important officials apparently saw this as a unique opportunity to force debtor countries to embrace the reforms that they believed were postponed by developing countries' easy access to credit before 1982. The call for "conditionality" found wide acceptance at international organizations and among academic economists that had favored greater official involvement with recycling.

\section{c. Analytical literature}

The academic literature immediately following the crisis followed a number of interesting lines of thought. The classic theoretical treatment on sovereign debt by Eaton and Gersovitz (1981) developed the idea that the key difference between a sovereign debtor and other credit markets was that the creditor could not seize collateral in the event of default. Thus, unlike a domestic credit a bank could not force liquidation of the firm and make the best of a bad loan judgement. For this reason the creditor had to rely on the ability to impose punishments on the debtor. Eaton and Gersovitz considered punishment in the form of trade sanctions, and the related loss in the gains from trade, and exclusion from future lending and the related loss of the debtor's ability to smooth consumption. This basic framework helped explain why a sovereign debt 
problem could take an extended time period to resolve. Since there was no outside arbiter to divide the collateral and "protect the debtor" from residual claims, default would be followed by prolonged renegotiation for partial payment. The basic insight provided by this theory is that a normal reaction to a sovereign default is a continuous renegotiation of payments based on the changing power of the two sides in an ongoing game.

But the emphasis on a game between a debtor and a representative creditor was adopted with too much enthusiasm by subsequent researchers. As discussed above, the idea that loss of reputation or fear of trade disruption was the basis for the enormous private loans extended to developing countries through 1982 is implausible.

More important from our point of view is the idea that the events following the debt crisis can be adequately modeled in a game that involved only debtors (developing country governments) and creditors (commercial banks), but left out the interested and relatively wealthy third party (industrial country governments), did not adequately capture the real nature of the problems generated by the crisis. An important exception is Bulow and Rogoff (1989c) where it is shown that governments of creditor countries may have good reasons to make side payments to banks and debtor countries in order to resolve conflict over repayment. In the context of the argument presented in this paper this might be seen as a reason for the 
banks to expect the creditor governments to make good on their implicit guarantee.

The refusal of creditor governments to "bail out the banks" was consistent with another important strand of academic research. This literature developed the idea that the debtors faced a temporary "liquidity" problem but were "solvent" in the long run. This judgement was based on calculations that suggested that the debt was small relative to the payments capacity of the debtor country. Influential studies by cline (1983) and Feldstein (1986) argued that a normal recovery of industrial countries from the recession would provide export markets to developing countries that would allow them to service their debt. This analysis fit the policy of concerted lending and conditional official lending to get the debtor countries over a brief liquidity crisis.

The issue of why banks refused to lend to solvent countries was addressed by a number of academic papers including Sachs (1984) and Krugman (1985). The basic idea in these papers is that the value of individual loans depends on the continued participation of other lenders. An individual bank would prefer to wait for other banks to make new loans so that it could receive full payment. This interesting literature followed the earlier convention of modeling a game between the debtor and a group of commercial banks. The argument was that the banks would find it difficult to organize themselves to make loans that were in their mutual interest. This literature recognized that there might be an expected loss to be 
distributed among the banks but pointed out that even a small expected loss could generate paralysis of new lending unless an outside force organized concerted lending. The "free rider" problem provided an elegant justification for concerted lending packages and appeared to explain the inability of private markets to lend to developing countries.

The above analysis is also consistent with the idea that an official debt facility (Kenen, 1983, 1990; Corden, 1989), or a private investor (Dooley, 1989), would have an economic incentive to buy all the existing debt and internalize the coordination problem. If debtor countries were solvent, this could be done at no expected cost.

Early proposals for a debt facility implicitly addressed the issue we turn to in the next section namely the coordination problem between official creditors, private creditors and potential investors in the debtor country. In retrospect, it is unfortunate that these proposals did not have more influence on the analytic work that followed. The conflict among the creditors is at least as important as the conflict between debtors and creditors in understanding the economic crisis for debtor countries that followed.

A debt facility would have resolved the conflict between the banks and official creditors. These proposals called for official creditors to fulfill their expected role, that is, to buy the debt from banks, perhaps at a discount, and hold these claims until the debtor countries benefitted from the expected 
turnaround in the world economy ${ }^{5}$. In one important sense these proposals focused on the key problem associated with the debt. The commercial banks expected to be taken out and viewed the refusal to do so, particularly by the United States government, as an ex post change in the rules of the game. The struggle that followed between the official and private foreign creditors left the debtor without a basis for entering into credible contracts with new creditors.

IV. Conflict among creditors and economic stagnation in the debtor countries

a. Historical review

The years following the crisis are marked by a prolonged struggle among broad groups of creditors and the related dismal economic performance of the debtor countries. The rough outline of how the creditors fared is shown in Table 2. At the end of 1982 debtor countries owed $\$ 278$ billion to commercial banks and $\$ 115$ billion to official creditors. Over the next seven years the real value of commercial bank debt fell to $\$ 241$ billion (1982 dollars) while the real value of official debt rose to $\$ 236$ billion (1982 dollars).

How did this happen? Clearly, the commercial banks did not forgive any of the debt and before 1989 only small amounts

5 See Dornbusch (1989, Ch. 5) for a comprehensive review of proposals for a debt facility. 
Table 2

Real Debt of Developing Countries

with Debt-Servicing Difficulties

(billions of 1982 dollars)

\begin{tabular}{|c|c|c|}
\hline & To Commercial Banks & To official Credicors \\
\hline 1982 & 278 & 115 \\
\hline 83 & 290 & 129 \\
\hline 84 & 286 & 143 \\
\hline 85 & 276 & 162 \\
\hline 86 & 278 & 187 \\
\hline 87 & 283 & 224 \\
\hline 88 & 254 & 232 \\
\hline 89 & 241 & 236 \\
\hline 90 & 222 & 251 \\
\hline 91 & 213 & 251 \\
\hline 92 & 200 & 252 \\
\hline \multicolumn{2}{|c|}{9} \\
\hline \multicolumn{2}{|c|}{ IMF World Economic Outlook } & \\
\hline
\end{tabular}


were exchanged for nondebt claims on the debtor governments. The answer is that most debtor countries made all their interest payments to commercial banks. Given an average inflation rate of about four percent in industrial countries this means that a debt of $\$ 100$ in 1982 on which all interest payments are made would still have a nominal value of $\$ 100$ in 1989. But the real value of debt would have fallen to about \$79. This is roughly what happened after 1983 . Where did the interest payments come from? In part they must have come from new credits provided by the official lenders and in part the interest payments were earned through net exports. This process insured that the historically unusual bulge in private lending in the 1970 s was being slowly returned to its historical norm as once again official credits dominated lending to developing countries.

The second important aspect of stage two is the dismal economic performance of the debtor countries. Table 3 shows growth rates for per capita GDP for developing countries with and without debt servicing difficulties. Slow growth in the industrial countries surely accounts for some of the slowdown of growth in the developing countries but, as discussed in detail below, it seems likely that the overhang of external debt also played a role in this weak economic performance. The third important institutional development was the emergence of a secondary market for external debt. As shown in Figure 1, starting in 1985 a well-organized secondary market allowed banks to buy and sell their participation in syndicated 
Table 3. Developing Countries: Growth in Per Capita GDP, 1972-91

\begin{tabular}{|c|c|c|c|c|c|c|c|c|c|c|c|}
\hline & $\begin{array}{l}\text { Average } 1 / \\
1972-81\end{array}$ & 1982 & 1983 & 1984 & 1985 & 1986 & 1987 & 1988 & 1989 & 1990 & 1991 \\
\hline Developing countries & 2.3 & -0.2 & -0.1 & 1.8 & 1.7 & 1.7 & 1.4 & 2.1 & 0.9 & 0.4 & 1.9 \\
\hline $\begin{array}{l}\text { Countries with recent deb } \\
\text { servicing difficulties }\end{array}$ & 1.7 & -2.0 & -3.9 & 0.4 & 1.1 & 1.3 & 0.3 & -0.2 & -0.5 & -2.5 & 0.8 \\
\hline $\begin{array}{l}\text { Countries without debt- } \\
\text { servicing difficulties }\end{array}$ & 3.5 & 3.3 & 5.1 & 5.8 & 4.8 & 4.2 & 5.3 & 5.6 & 2.6 & 3.5 & 3,4 \\
\hline
\end{tabular}

Source: IMF World Economic Outlook (October 1990)

If Compound annual rates of change. Excluding China. 
Secondary Market Prices for Developing Country Debt (1986 - 1993)

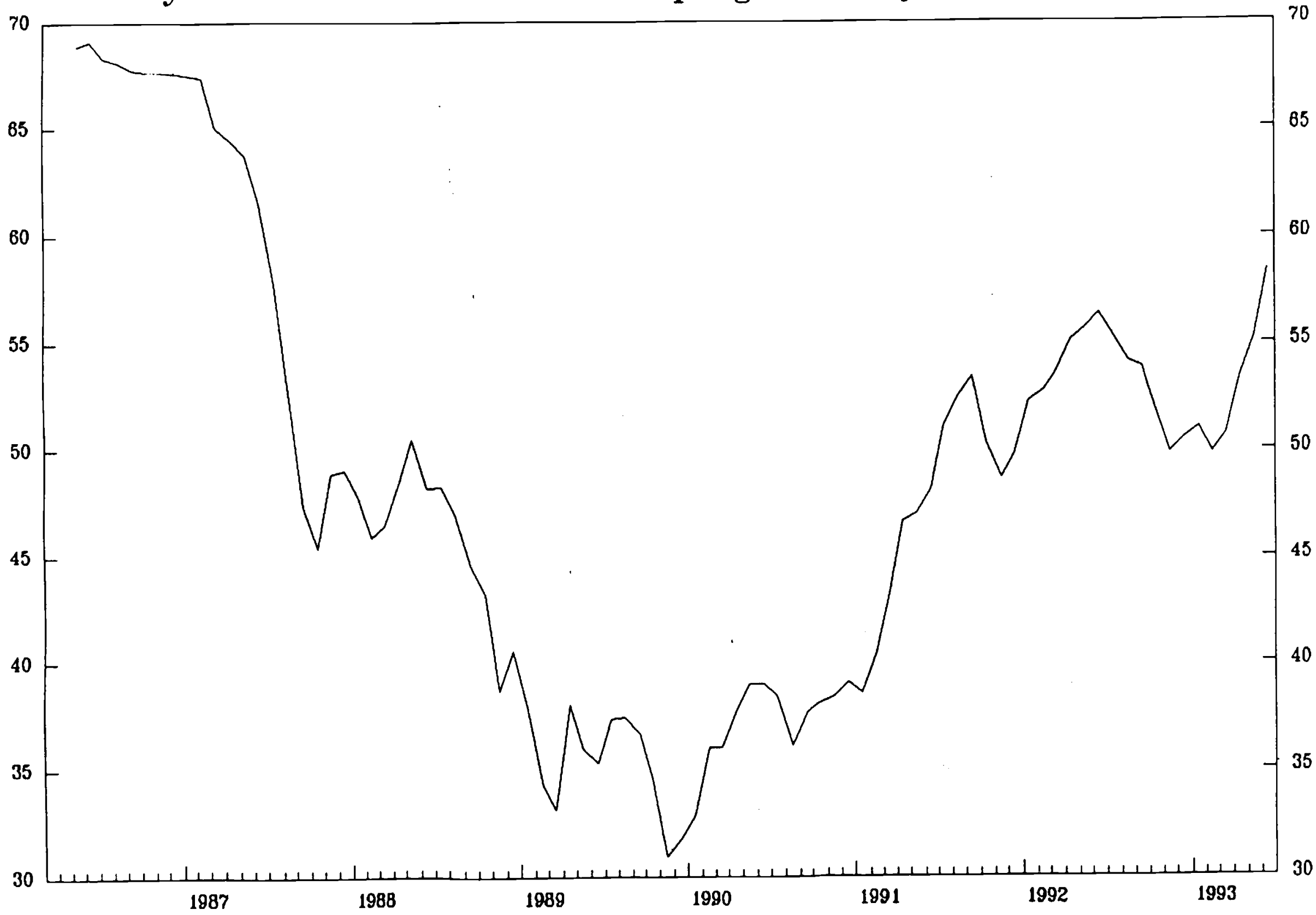


credits. The market is important because it gives a sensitive barometer of the expected value of future payments on this type of debt. In 1985 and 1986 prices settled at about $\$ 0.60$ per dollar of face value. If a credit was supposed to pay LIBOR plus a typical spread of about one percent this means that the secondary market yield was roughly (LIBOR +.01$) / 0.60$. Thus falling prices through 1989 indicated that an increasing risk premium was demanded by investors to induce them to hold the existing stock of bank debt.

b. Policy of muddling through.

Regardless of the merits of the case, a comprehensive debt facility was politically unacceptable in most creditor countries. The preferred alternative was "concerted rescheduling" in which all creditors did their "share" in providing credit to debtor countries. The banks cleverly called their contribution "new money" which, in reality, was neither new nor was it money. An only slightly cynical view of this process is that the banks organized the official creditors rather than the reverse.

This strategy was formalized in the Baker Plan announced in 1985. The essence of the plan was that industrial country governments would provide (a little) new lending to the debtor countries, both directly and through the international institutions they both financed and controlled, and would thereby "catalyze" a (large amount) of new credits from the banks. The Baker Plan added "catalyze" to the list of terrible 
jargon of international finance, but did not result in new lending by the banks. As shown above, the key in interpreting how private and official creditors were working out their relative positions during this phase of the crisis is to look at their balance sheets rather than listening to what they said.

The banks were the clear winners of this phase of the game because the expected bailout was forthcoming, but very slowly, as official debt gradually displaced bank debt. In my view, the banks understood the nature of the game very well but, of course, were not anxious to discuss the matter in these terms ${ }^{6}$. The official sector was less well informed. In retrospect, it seems to me that for a long time the strategy that was intended to force the banks to continue to lend while the debtor countries embarked on reform programs worked in the narrow interests of the banks.

It was and is easy to miss the essential nature of this game between the banks and their governments. The argument did not usually explicitly focus on which creditor would receive interest payments but instead on the mirror image question of which creditor would make a new loan. Given payments from the debtors' resources, making a new loan is the same thing as giving a payment to the other creditor. Neither the banks or the creditor governments saw excessive clarity in presenting

6 Cohen (1992) and Calvo (1989) provide an interesting calculation of the ex post returns realized the banks over the whole period. 
their position as an advantage. Banks were winning the game as it was being played and governments that had taken the position that they would not "bail out the banks" were not anxious to concede that they were doing slowly what they would not do quickly.

\section{c. Analytical Literature}

This phase of the debt crisis can be interpreted as a protracted negotiation between heavily indebted developing countries and creditors and, in my view more importantly among creditors, to rationalize contracts and implicit contracts that could not be carried out as written or understood by various participants. As discussed above the analytic literature immediately following the crisis emphasized the conflict between a debtor and a representative creditor. This framework continued to dominate the subsequent literature that turned to the question of the effects of debt on economic performance of debtors and analyses of the effects of debt forgiveness. As outlined above an important aspect of this phase of the crisis was the miserable economic performance of the debtor countries. The key to the academic literature that addressed this issue was to model the relationship between existing debt and economic performance.

One approach (Sachs, 1988; Krugman, 1989; Froot, 1989; Helpman 1989, 1990; Dooley and Helpman 1992) was to model debt service payments as a tax on future output. Like any expected tax on current investment debt service can be expected to 
discourage investment and encourage current consumption in debtor countries. The link between the contractual value of debt and its market value can be summarized in a "debt Laffer curve" that relates the stock of debt to its market value. The market value of debt increases as the stock of debt rises as long as tax receipts rise. But as the tax rate rises the disincentives from a higher tax rate eventually generate a decline in investment and income that dominates the increase in tax rates.

These models emphasize the behavior of the debtor in evaluating the effects of a debt overhang and debt reduction. Forgiveness of debt is in the interest of creditors as a group if the country is on the wrong side of the debt Laffer curve. That is, only if the market value of debt rises as debt is forgiven. Empirical estimates of the relationship between the stock of debt and its market value suggest that very few debtor countries have been in such a position (Claessens 1990).

An alternative approach developed by Dooley (1986) focuses on the behavior of various groups of existing and potential creditors. This approach emphasizes the expected sharing of a given pool of debt service payments among creditors. It seems clear in retrospect that there are at least four important classes of creditors of governments of debtor countries. These include banks, official creditors, domestic creditors and potential investors in real capital in the debtor country. 
Potential investors in a debtor country are the most important and least obvious of the government's creditors. Investors are creditors because they implicitly enter into a tax contract with the government that sets out how revenues are shared with the government. In that sense potential investors are offered contracts by governments that are similar to those held by the internal and external creditors. In an environment where there is uncertainty concerning the government's ability to satisfy its obligations all creditors and potential creditors will position themselves to maximize their payment at the expense of other creditors. A new investor has the option of moving to a country that does not have a debt overhang.

The interdependence among creditors suggests that there is a strong relationship between the market return available on existing debt and the rate of return on additions to the capital stock located in the debtor country. Since rates of return on existing debt by 1986 had risen to four to ten times the risk- free interest rate this argument suggested that existing creditors expected to be subject to a very high marginal tax rate. If new investors expected to be subject to that same marginal tax rate few new investment projects could plausibly promise such a high rate of return. The critical issue is the expected seniority of various creditors. The assumption that all existing and potential creditors face the same expected marginal tax rate seems the most appropriate. Dooley and Svensson (1993) show that it is difficult for a 
debtor government to credibly establish seniority that would protect a new investor from existing creditors.

The interdependence of old and new creditors has important implications for the behavior of individual creditor groups. For example, for the commercial banks as a group unilateral debt reduction that made sense in the context of the debt Laffer curve discussed above would generate capital gains for official creditors, domestic creditors and taxpayers in the debtor countries.

More important, if transfers to the debtor by official creditors were related to the level of misery in the debtor country, banks had even less reason to be concerned about the negative incentives for investment generated by a debt overhang. It is possible in this situation that even if a country was on the "wrong " side of a debt Laffer curve (so that debt forgiveness by banks would increase expected payments by debtors), the gain for the banks would be more than offset by lower expected transfers from official creditors because of better economic conditions in the debtor country.

In summary, an emphasis on the interdependence of creditors is based on the view that the banks did not see much payoff in trying to influence the behavior of debtor country governments. In contrast, commercial banks are familiar with influencing their own governments and, in crude terms, that is where the money was to be found.

The economic consequences of what came to be known as a "debt overhang" have been evaluated in a number of empirical 
models (Cohen, 1992; Borensztein, 1990). There remains a wide range of opinion about the importance of the overhang for the economic performance of debtor countries, and therefore about the benefits from reducing debt through various techniques, it seems very likely that among the players in this game the debtor countries had most to lose from the inability of the banks and the official creditors to resolve their conflict.

\section{Confrontation among creditors}

a. Historical review

The rescheduling of Mexico's debt in 1986 was the beginning of a new and more confrontational relationship between the official and bank creditors. Periodic reschedulings were necessary because most external debt had been combined into a multi-year rescheduling agreement that had to be renegotiated every few years. Naturally, each creditor saw these negotiations as opportunities to reduce their exposure on terms better than they could get on the secondary market. But the real problem was not coordination among the banks. In my view banks did not believe they could gain much at the expense of other banks. The real payoff was in convincing official creditors to increase lending.

The 1986 negotiations were different in that they started with an explicit statement by the Mexican government as to the interest payment to be made to banks expressed initially as a percent of GDP. This opening bid by the debtor forced official creditors to take a stand on whether the Mexican offer was 
"reasonable" in light of the debtor's economic condition. In addition it was clear that any "financing gap" between the debtor's offer and the banks' counter-offer would have to be filled by official credits. If the official creditors did not provide the residual financing no agreement was possible and interest arrears would emerge. The banks felt abused in this negotiation in that the creditor governments reportedly assigned "new money" quotas to the banks.

Shortly after this episode U.S. banks created substantial loan loss provisions against their developing country debt and market prices for all sovereign debt fell dramatically. The initial Mexican offer put all creditors on notice that the debtor countries were unwilling or unable to continue to tap domestic credit markets in order to make external debt payments. The resulting fall in market prices is the natural consequence of the fall in the de facto senior status relative to other creditors that bank debt had enjoyed since $1982^{7}$.

b. Policy options

The showdown in the Mexican deal in 1986 clarified the conflicting interests of creditors. It clearly demonstrated that the official and bank creditors were competing for the same limited pool of payments from the debtor countries. The insistence on the part of official creditors that banks provide

See Dooley and stone (1993) for an empirical analysis of this conjecture. 
new money was identically equal to the insistence that their own lending not be used to amortize bank claims.

At the same time, the fall in market prices for the debt made the proposition that the debtors were solvent increasingly hard to sell. The substantial discounts on secondary markets seemed to offer the official creditors better terms for reducing bank claims than they were getting through concerted lending packages. After all, interest payment to another creditor is a buy-back at a price of unity. Moreover, the process of slowly taking the banks out was proving very tough on the debtor countries.

The Brady Plan was an amazingly muddled attempt to deal with the conflict. The original Brady Plan proposal was thought by those who proposed it to offer a great deal of debt reduction at little cost to the official creditors that would provide the resources. Those with a more analytic frame of mind, including the banks, recognized that the resources available to support the plan would generate a lot of debt reduction only if the banks were given no choice but to sell at existing market prices which at the time the plan was first announced had reached a low of about $\$ 0.30$ on the dollar ${ }^{8}$. In contrast, the U.S. Treasury never had any intention of making the plan mandatory. Their view was that each agreement would

${ }^{8}$ See Krugman (1988b) and Dooley and Symansky (1988) for an analysis of why the ancillary aspects of the Brady rescheduling agreements did not allow official resources to retire more debt than is suggested by a simple buy-back at prices expected to prevail after the buy-back. 
be purely voluntary. In a way this was a practical point of view because it was not clear how the United States' government could force the banks to accept an agreement that was contrary to the interests of the banks' shareholders. ${ }^{9}$

The result, in addition to a good deal of confusion, was a protracted series of negotiations that usually commenced with the debtor expecting and asking for a large amount of debt reduction but an agreement that, in the end, involved debt reduction at prices that reflected the market's view of the value of debt remaining after the debt reduction. For this reason the amount of debt reduction was quite limited in the Brady deals, especially when new official debt is added to the calculation of net debt reduction ${ }^{10}$.

As late as the Spring of 1990 economists agreed that the scale of debt reduction possible under voluntary deals could not make a material difference in the fortunes of the debtor countries (United States Senate, 1990; Dornbusch, 1989 and Kreuger, 1989).

\section{b. Analytical literature}

The main topic in the theoretical literature relevant to this phase of the crisis was the analysis of debt reduction and

9 The Federal Reserve was particularly hostile to forced writedowns of debt. They rightly questioned the practical difficulties in defining and administering an equitable administrative restructuring (Volcker and Gyohten,1992).

10 See Claessens, Diwan and Fernandez-Arias (1992) for a careful evaluation of Brady Plan agreements. 
restructuring. An important issue was the extent to which a secondary market discount on sovereign debt offered an opportunity for official creditors to purchase the debt cheaply, forgive a portion of the contractual value, and enjoy the capital gains on the remaining debt when the debtor economies revived.

A very simple analysis made it clear that any voluntary transaction would generate a rise in the price at which the debt could be purchased, since the expected value of existing debt would rise (Dooley, 1988; Bulow and Rogoff 1988, 1989a). This placed the official creditors in direct and open conflict with the commercial banks. If, for example, industrial country governments offered to buy all private debt and forgive all of it, an individual bank would hold out and expect to receive full payment following the deal. The obvious solution would be to threaten to default on any debt not sold at a price set by the buyer. But the industrial country governments refused to pressure banks into such a position.

In practical terms, this has meant that the market value of claims surrendered by the banks in a Brady restructuring had to be comparable to the expected market value of the new claims or cash acquired. If this condition was not met, the banks have had the option of refusing to grant waivers necessary for a restructuring and waiting for a better offer. The banks were "held together" by the requirement in existing credits that 60100 percent of participants vote to approve waivers necessary for a restructuring agreement. The creditor governments that 
financed the deals also had the option to set conditions and wait for a better deal and it follows that the division of the surplus provided by the debtor governments between the banks and the debtors reflected the relative bargaining power or impatience of the banks and their governments.

In an extreme case where the creditor governments have no bargaining power, it is clear that once the resources available for the buy-back are known to the market, the market price will be set equal to a rational forecast of the value of debt after the buy-back. Some simple arithmetic will help develop the point (Dooley, 1988a, 1988b). Suppose the expected present value of payments from the debtor is $\$ 100$. Initial debt consists of dollar-dominated loans--\$100 "bank debt" held by foreign banks and $\$ 100$ "official debt" held by creditor governments. Suppose also that all creditors expect to share all future payment strictly in proportion to the contractual value of their claims. This is sometimes called an equal sharing clause and it is found in all syndicated credit agreements. The market price of both types of debt would be $\$ 0.50$, the expected present value of payments divided by the contractual value of total debt. If official creditors lend $\$ 10$ to the debtor government for a buy-back, it is clear that the debt remaining after the restructuring will be $\$ 210-$ $\$ 10 / p$, where $p$ is the price at the time of the transaction. If market participants are rational, they will set $p$ at the level expected to prevail following the restructuring. Setting the buy-back price equal to the expected market price, 


$$
\begin{aligned}
p & =\$ 100 /(\$ 210-\$ 10 / p) \\
& =\$ 0.524
\end{aligned}
$$

It follows that the rise in the market price generates a capital gain for the banks, a net loss for the official creditors, and no direct gain for the debtor."1 In addition the scale of debt reduction possible is constrained by the resources available to compensate creditors.

In most restructuring agreements a menu of options has been offered to the banks. The basic points made above, however, are not altered by an expansion of the instruments involved. For example, most agreements include a variety of new bonds, often convertible into equity, that carry guarantees of interest and/or principal. However, as long as the assumption of equal sharing is maintained, a new instrument can be decomposed into country risk that will sell for the same price as all other old and new claims on the country and a risk-free component due to the collateral behind the guarantee. Arbitrage conditions insure that if the same $\$ 10$ was used to collateralize principal and interest of a new instrument that an exchange of old for new debt would generate the same equilibrium as above.

11 See Dooley, Haas and Symansky (1993) for an accounting framework for evaluating the effects of debt restructuring on various classes of creditors. 
A related issue is whether or not voluntary debt reduction is an efficient use of resources. The fact that banks realize capital gains as debt prices rise suggests that most of the benefits might go to existing creditors rather than the debtors. In the above example it is difficult to see what difference a small amount of debt reduction could make for the debtor. A market price of $\$ 0.524$ rather than $\$ 0.50$ is unlikely to generate a measurable change in the investment in the debtor country (Dooley 1988a, Bulow and Rogoff, 1988). The debtor might be better off to keep resources and invest in reserves or domestic activities.

A buy-back makes more sense in the context of a three party game when one of the existing creditors is financing the buy out of another creditor. In the simple example above the official creditor makes a new loan that immediately falls to a discount on the secondary market. This loss can be interpreted as a side payment by one creditor to another. The circumstances under which this is a rational policy choice are presented in Bulow and Rogoff (1989c). The contribution of this framework is that it shows that a range of outcomes are possible depending on the preferences and market power of lenders. For example they show that if lenders are competitors and thus have no market power, side payments from creditor governments will go entirely to the debtor. This framework also helps clarify the extent to which the market value of the debt depends on expected side payments from the creditor governments and expected payments from the debtor. 
It is certainly possible that the Brady restructuring agreements were able to exploit the power of creditor governments to force the banks to make concessions in order to consummate the deals. In fact, empirical evaluations of the agreements suggest that the debtor countries and the banks shared the surplus generated by side payments from creditor governments about equally (Van wijnbergen 1990; Bulow, Rogoff and Bevilaqua 1991; Claessens, Diwan, and Fernandez-Arias, 1992). Nevertheless, as shown in Dooley (1993) it is difficult to rule out the possibility that all the direct benefits of Brady deals to date went to the banks. Moreover, it is generally agreed that the direct benefits of Brady restructurings have been too small to account for much of the increase in the secondary market prices since 1990.

VI. Another debt buildup 1990-1993

a. Historical review

Why then have the financial positions of debtor countries improved since 1990? As mentioned in the introduction, private capital inflows into Brady Plan countries have been very strong, prices for external debt have risen, and stock and real estate markets have seen large increases in prices. Is the debt crisis dead as suggested by several observers recently? or is it only sleeping?

As documented by Bacha (1991) the increase in debt prices has been larger for Brady Plan countries as compared to other 
debtor countries. ${ }^{12}$ There are some good reasons to guess that the crisis is over for some countries. An important aspect of the turnaround in some countries was a clear change in economic policies. In Mexico, Argentina, and Chile, for example, impressive reform programs have included substantial increases in the primary budget surpluses and amortization of internal and external debt. In addition, privatization of important financial and nonfinancial enterprises and significant opening to foreign competition promises to provide a lasting improvement in the return on investment.

For these countries the relative contribution of debt reduction and economic adjustment is difficult to disentangle but for the purpose of assessing the permanence of the turnaround this makes little difference as long as policy reforms are maintained.

But even in these cases reversible good luck also appears to have played a role. The rise in international interest rates that caused the problem in the first place was gradually reversed after the first quarter of 1989 and real interest rates have fallen to very low levels by historical standards. This will not last as the industrial countries recover from the current recession and real interest rates begin to regain historically normal levels.

${ }^{12}$ Bacha includes Chile even though their debt reduction program relied on debt equity swaps rather than a formal restructuring. 
The recovery in debt prices since 1989 has been highly correlated with the fall in real and nominal interest rates in industrial countries. This comovement is consistent with the possibility that expected payments by debtor governments are independent of market interest rates, so that the market value of the debt rises as expected payments are discounted at lower interest rates (Cohen and Portes 1990; Dooley and stone 1993). But we do not have a good statistical model of debt prices that would discriminate among reasonable alternative hypotheses.

Thus, it is certainly possible that the important forces behind the recent return of many debtors to markets could be quickly reversed. But the argument developed in this paper suggests that the consequences for debtor countries might be less serious as compared to 1982 for the subset of countries that have restructured their external bank debt. In particular, a fall in the expected value of the new debt would not generate the drawn out conflict among creditors that characterized the previous experience.

By the same logic, however, countries that still have a large stock of floating rate bank debt, and arrears on that debt, could be very vulnerable to a new period of economic stagnation. It should be remembered that only a handful of countries have taken advantage of the improved climate since 1990 to reduce or transform a significant part of their debt. 
Recent capital inflows to Brady Plan countries may well generate capital losses for investors but it is unlikely that the debtor countries will suffer from a debt overhang. In the recent case foreign investors have acquired domestic currency claims on the developing countries. This might suggest that relatively painless (from the debtors' point of view) currency depreciation would reduce the value of debt if expectations change. A qualification of this argument is that in many cases debtor governments have staked the credibility of their antiinflation program on maintaining a fixed nominal exchange rate. Moreover, the debtor governments have accumulated large reserve positions that would presumably be used to defend the exchange rate.

To reduce the chances that private debts will become socialized this time, some debtor governments have placed limits on their commercial banks' foreign borrowing or imposed high reserve requirements against foreign deposits in order to limit the governments' implicit guarantee of such deposits. However, if the incentives for capital inflows are not reduced, foreign borrowing by domestic nonbanks will surely replace borrowing by banks. Moreover, should foreign creditors call in loans, domestic banks might not be able to let firms with large domestic bank loans default to foreign lenders without calling into question their own claims on these firms. Thus, it appears at least possible that private domestic currency debt could once again be quickly transformed into government 
liabilities effectively denominated in dollars because of the fixed exchange rate.

The important difference is that commercial banks in industrial countries are not the lenders this time. Instead, investors, including residents of the debtor countries, have acquired claims on developing countries through a variety of nonbank financial intermediaries. Intermediaries include high yield bond funds and emerging market equity funds located in both industrial and developing countries. These intermediaries are unlikely to receive much sympathy from the creditor governments if losses on their holdings should occur. A tentative conclusion is that there will be winners and losers in this new round of debt accumulation in developing countries but recent inflows will not set the stage for a repeat of the 1982 crisis.

In contrast, debtor countries that still have large stocks of floating rate bank debt outstanding are vulnerable to a continuation and intensification of the economic consequences of a decade long failure to resolve the debt overhang from the 1970s. In fact, attention should now focus on the majority of countries that have not taken advantage of the recent decline in interest rates or the availability of official credit to finance debt reduction. 
Bacha, Edmar L., "The Brady Plan and Beyond: New Debt

Management options for Latin America," Texto para Discussao No. 257, May 1991, Departamento de Economia, Pontificia Universidade Catolica do Rio de Janeiro.

Borensztein, Eduardo, "Debt overhang, Credit Rationing and Investment," Journal of Development Economics, 32, April 1990, pp. 315-335.

Bulow, Jeremy, and Ken Rogoff, "The Buy-Back Boondoggle," Brookings Papers on Economic Activity, 2, November 1988, pp. $675-704$

Sovereign Debt," Journal of Political Economy, 97, February 1989a, pp. 166-177.

- Is to Forgive 'to Forget',"

American Economic Review, 79, March 1989b, pp. 43-50.

Rescheduling Developing Country Debt," in Jacob Frenkel,

Michael Dooley and Peter Wickham, eds., Analytical Issues

in Debt, International Monetary Fund, 1989c, pp. 194-207. -

Overhang," Quarterly Journal of Economics, 96, June 1991. Bulow, Jeremy, Ken Rogoff and Afonso S. Bevilaqua, "Official Creditor seniority and Burden-sharing in the former soviet Bloc. Brookings Papers on Economic Activity (U.S.), 1, 1992 , pp. 195-234. 
Burns, Arthur F., Reflections of an Economic Policy Maker: Speeches and Congressional statements, 1969-1978, American Enterprise Institute for Public Policy Research, Washington, DC, 1978 .

Calvo, Guillermo A., "A Delicate Equilibrium: Debt Relief and Default Penalties in an International Context." in Jacob Frenkel, Michael Dooley and Peter Wickham, eds., Analytical Issues in Debt, International Monetary Fund, 1989, pp. 172193.

Calvo, Guillermo A., Leonardo Leiderman and Carmen M. Reinhart, "Capital inflows and real exchange rate appreciation in Latin America: the role of external factors," IMF staff Papers, 40, March 1993.

Claessens, Constantijn, "The Debt Laffer Curve: Some Estimates," World Development, 18, 1990, pp.1671-1677. Claessens, Constantijn, and Sweder Van Winjbergen, "Secondary Market Prices Under Alternative Debt Reduction Strategies: An option Pricing Approach with an Application to Mexico," World Bank, 1990, unpublished. Claessens, Stijn, Ishac Diwan and Eduardo Fernandez-Arias, "Recent Experience with Commercial Debt Reduction", World Bank Working Parer Series No. 995, October, 1992. 
Cline, william R., International Debt and the stability of the World Economy, Institute of International Economics, Washington, DC, 1983 .

Cohen, Daniel, "The Debt Crisis: A Postmortem," NBER

Macroeconomic Annual, 1992, pp. 64-114.

- Private Lending to Sovereign states,

Cambridge, MIT Press, 1991.

(1) and Richard Portes, "The of LDC

Debt," CEPR Discussion Paper No. 459, 1990.

Cooper, Richard N., Economic Stabilization and Debt in

Developing Countries, Cambridge, MIT Press, 1992.

Corden, Max, "An International Debt Facility," in Jacob A.

Frenkel, Michael P. Dooley, and Peter Wickham, eds.,

Analytical Issues in Debt, International Monetary Fund, 1989, pp. 151-171.

Devlin, Robert, Debt and Crisis in Latin America: the Supply

Side of the Story, Princeton, Princeton University Press, 1989.

De Vries, Margaret Garritsen, "The International Monetary Fund, 1972-1978: Cooperation on Trial," Washington, International Monetary Fund, 1985.

Diwan, Ishac, and Kenneth Kletzer, "Voluntary Choices in Concerted Deals," World Bank Working Paper No. 527, 1990. 
Diwan, Ishac, and Dani Rodick, "Debt Reduction, Adjustment Lending, and Burden Sharing," NBER Working Paper 4007, March 1993. Forthcoming, Essays in International Finance, Princeton.

Dooley, Michael P., "Country Specific Risk Premiums, Capital Flight and Net Investment Income Payments in Selected Developing Countries," Washington, International Monetary Fund, 1986.

Finance and Development, 24, March 1987, pp. 6-9.

External Debt," IMF Staff Papers, 35, June 1988a, pp. 215229.

Exchanges," Staff Papers, 35, December 1988b, pp. 714722 .

International Economics Review, 30, February 1989, pp. 7175 .

Dooley, Michael P., and, W. Max Corden, "Issues in the Debt Strategy: An Overview," in Jacob Frenkel, Michael Dooley, and Peter Wickham, eds., Analytical Issues in Debt, International Monetary Fund, 1989, pp. 10-37. 
Dooley, Michael P., Fernandez-Arias, Eduardo and Kenneth Kletzer, "Recent Private Capital Inflows to Developing Countries: Is the Debt Crisis History?" NBER Working Paper \#4792, July, 1994.

Dooley, Michael P., Richard Hass, and steven Symansky, "A Note on Burden Sharing Among Creditors," IMF Staff Papers, 40, 1993, pp. 226-232.

Dooley, Michael P., W. Helkie, J. Underwood, and R. Tryon, "An Analysis of External Debt Positions of Eight Developing Countries through 1990," Journal of Development Economics, 21, May 1986, pp. 283-318.

Dooley, Michael P., and Elhanan Helpman, "Tax Credits for Debt Reduction," Journal of International Economics, 32 , February 1992, pp. 165-177. Dooley, Michael P., and Mark stone, "Endogenous Creditor Seniority and External Debt Values., IMF staff Papers, 40, June 1993, pp. 395-413.

Dooley, Michael P. and Lars Svensson, "Policy Inconsistency and External Debt Service," IMF Working Paper/90/103, April 1990.

Dooley, Michael P., and Steven Symansky, "Comparing Menu Items: Methodological Considerations and Policy Issues," in Michael Dooley, and Peter Wickham, eds., Analytical Issues in Debt, International Monetary Fund, 1989, pp. 398-411. 
Dornbusch, Rudiger, "Our LDC Debts," in Martin Feldstein ed., The United states in the World Economy, Chicago: University of Chicago Press.

Dornbusch, Rudiger, The Road to Economic Recovery: Report of the Twentieth Century Fund Task Force on International Debt, New York: Priority Press, 1989. Eaton, John, and Mark Gersovitz, "Debt with Potential Repudiation: Theory and Estimation," Review of Economic Studies, $48,1981, \mathrm{pp} .289-309$.

Feldstein, Martin, "International Debt Service and Economic Growth - Some Simple Analytics," NBER Working Paper 2046, 1986.

Folkerts-Landau, David and Carlos Alfredo Rodriguez, "Mexican Debt Exchange: Lessons and Issues," in Jacob Frenkel, Michael Dooley, and Peter Wickham, eds., Analytical Issues in Debt, International Monetary Fund, 1989, pp. 359-371. Friedman, Irving, The Emerging Role of Private Banks, Citicorp, 1977.

Froot, Kenneth, "Buy - Backs, Exit Bonds, and the Optimality of Debt and Liquidity Relief," International Economic Review, 30, February 1989, pp. 45-70.

Guttentag, Jack H., and Richard Herring, "Disaster myopia in international banking," Princeton, NJ: Princeton University Press, International Finance Section, 1986. 
Helpman, Elhanan, "Voluntary Debt Reduction: Incentives and Welfare," IMF Staff Papers, 36, September 1989, pp. 580611.

"The Simple Analytics of Debt Equity

Swaps," American Economic Review, 79, 1990, pp. 440-451. Kenen, Peter, "A Bailout for Banks," New York Times, March 6, 1983 .

"Organizing Debt Relief: The Need for

a New Institution," Journal of Economic Perspective, 1990. Kereken, John H., Discussion, Brookings Papers on Economic Activity, 2, 1977, pp. 505-508.

Kletzer, Kenneth, "Asymmetries of Information and LDC Borrowing with Sovereign Risk," Economic Journal, 94, 1984, pp. 287307 .

Asymmetric Information," in Jacob Frenkel, Michael P. Dooley, and Peter Wickham, eds., Analytical Issues in Debt, International Monetary Fund, 1989, pp. 208-241. Krueger, Anne 0., "Resolving the Debt Crisis and Restoring Developing Countries' Creditworthiness," in Karl Brunner and Allan H. Meltzer, eds. International Det. Federal Reserve Operations and Other Essays, Carnegie-Rochester Conference Series on Public Policy 30, 1989. 
Krugman, Paul, "Financing vs. Forgiving a Debt Overhang: Some Analytical Notes," Journal of Development Economics, 29, December 1989a, pp. 253-268.

- Market Based Debt-Reduction Schemes," in Jacob Frenkel, Michael P. Dooley, and Peter Wickham, eds., Analytical Issues in Debt, International Monetary Fund, 1989b, pp. 258-278.

(International Debt strategies in an Uncertain World," in Gordon Smith and John Cuddington, eds., International Debt and the Developing Countries, Washington, World Bank, 1985. Rout, Lawrence, The Wall street Journal, March 3, 1983. Sachs, Jeffrey D., Theoretical Issues in International Borrowing, Princeton studies in International Finance No. 54, Princeton, NJ: Princeton University, International Finance Section, July 1984. , New Approaches to the Latin American

Debt Crisis, Essays in International Finance No. 174, Princeton, NJ:

Princeton University, International Finance Section, July 1984

Brookings Papers on Economic Activity, 2, 1986. 


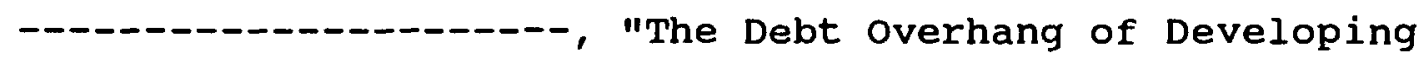

Countries, in J. de Macedo and R. Findlay, eds., Debt, Growth, and Stabilization: Essays in Memory of Carlos Dias Alejandro, oxford: Blackwell, 1988 .

-

Economy, Cambridge Mass.: NBER, 1989.

Solomon, Robert, "A Perspective on the Debt of Developing

Countries," Brookings Papers on Economic Activity, 2, 1977 , pp. $479-510$.

United states senate, Implementation of the Brady Plan, Hearing before the Subcommittee on International Debt of the Committee on Finance, March 2, 1990.

Van Wijnbergen, Sweder, "Mexico's External Debt Restructuring in 1989/90: An Economic Analysis," Economic Policy, 1990. Volker, Paul A., and Toyoo Gyojten, Changing Fortunes: The World's Money and the Decline of American Supremacy, New York: Time Books, 1992 .

Wallich, Henry C., "LDC Debt ... to worry or not to Worry," Challenge, 24, September/October 1981, pp. 28-34.

of Last Resort in an International context: A View from the United States, New York: St. Martin's Press, 1987. Weintraub, Robert E., International Lending by U.S.Banks: Practices, Problems, and Policies, Fairfax, VA: George Mason University, August 1983. 
Wellons, Phillip A., Passing the Buck: Banks, Governments, and Third World Debt, Boston, MA: Harvard Business School Press, 1987.

Whitman, Marina v.N, "Bridging the Gap," Foreign Policy, 30, Spring 1978, pp. 148-156. 